\title{
On Developing Instruction Materials in Inculcating Secondary Students' Mathematical Reasoning Skills
}

\author{
E. Elvis Napitupulu \\ Mathematics Department \\ State University of Medan \\ Medan, Indonesia \\ elvisnapit@gmail.com
}

\begin{abstract}
Learning Mathematics with understanding is essential. Grasping it absolutely needs reasoning for every conclusion drawn, one draw it deductively. Many report either formerly or recently revealed the lack of upper secondary students' mathematical reasoning skills (MRS). Concerning this case, the paper reports some results of a research aimed to develop instruction materials, which is designed based on problem-based learning to inculcate upper secondary students' MRS. The materials consist of students' book, work sheet, and instrument to measure the intended skills. The development followed the 4-D model. Three expert validators judged the materials are valid with slight revision. By trials, teachers and students considered it feasible to conduct in classroom. Test on MRS showed a low increasing in students' achievement. It concluded than that the materials developed is effective to inculcate students' MRS.
\end{abstract} skills

Keywords: instruction materials, $P B L$, mathematical reasoning

\section{INTRODUCTION}

Mathematical reasoning is one of the five cores of doing mathematics students should grasp at every level of school [1 and 2]. In effort to solve problem, one needs understanding and to understand problem he needs reasoning absolutely. By reasoning, one polishes and develops his ability to use pattern and properties; manipulates mathematically to generalize; and poses proof or explains mathematics ideas or proposition [3]. These show mathematical reasoning is essential and the heart of problem solving.

Though the ultimate role mathematical reasoning plays in solving problem, many researchers reported the lack of Indonesian students in mathematical reasoning skills (MRS) in all level [4, 5, 6, and 7]. Reference [4] revealed Indonesian eight graders only achieved $17 \%$ meanwhile international average was $30 \%$. Fourth graders only grasped $20 \%$ comparing to international average $40 \%$ [5]. Similar result founded in [6]. At upper secondary students, reference [7] noted they only got $36.56 \%$. Overall, MRS of Indonesian students is inadequate.

One of the responsible to the low achievement in MRS is hypothesized strongly due to the processes of teaching and learning conducted in Indonesian mathematics classrooms. Many researchers reported direct instruction still dominates
Indonesian's mathematics classrooms [4, 7, and 8]. Teachers rarely give their students space and time to connect their previous knowledge to construct new ones. There did not exist any challenge to build conjecture and prove it, nor any challenge to explain mathematics idea or proposition. Students then are accustomed to receiving lessons passively. Furthermore, they only able to handle routine exercises similar to the ones their teachers gave.

Considering the fact, Indonesian Government via The Ministry of Education and Culture launched 2013-Curriculum, nowadays implemented in Indonesian schools. The new Curriculum appeals for adopting and using scientific approach to conduct mathematics lessons as part of models or approaches teachers use in classrooms. This approach, which constitutes of observing, questioning, experimenting, reasoning, and communicating, would enable students to develop their scientific skill especially in reasoning. To accelerate the dissemination of the teaching approach used in classrooms, the Indonesian Government then integrate it in Teacher Certification Program.

Conducting mathematics lessons based on scientific approach is one of many major problems for majority of Indonesian mathematics teachers [9]. For a long time, they are used to teaching mathematics directly from the textbook available by the government [10]. Preliminaries survey to some schools involved in the study revealed similar result. They lack of ability as well as practice to design instruction materials to pursuing mathematical reasoning skills. Besides, they also lack of knowledge and experiences in conducting lesson under scientific circumstance. As this is the case, this research is also intended to initiate and empower teachers engaged in the research to be capable and have goodwill to create mathematics classrooms as the 2013-Curriculum desires.

The 2013-Curriculum endorses teachers to implement several models of teachings; among others is problem-based learning (PBL). As a model based on constructivism paradigm, PBL leads, nurtures, and facilitates students to become problem solvers. Problem triggers such that learning take place. Students, in-group, apply their previous knowledge and experiences to solve it. By solving the problem, they construct new knowledge, grasp skills, and experience with 
mathematical reasoning as main tool. By reasoning, they connect information given in a problem to the database stored in their memory and draw conclusion what next should be put in place accordingly. By reasoning too, they think hardly to reveal pattern or properties contained in the problem. In addition, by reasoning they should manipulate mathematically to be able posing a generalization, a conjecture, or a proof, and explaining a mathematical idea. Doing so, students' mathematical reasoning skill will inherently improve.

In PBL, students' previous knowledge and experience form basis to handle tasks the teacher poses. Teacher should confirm that his students are ready to continue learning with adequate previous knowledge and skill. If it is not the case, he should pay attention to review essential materials supporting the continuation of learning though do it briefly.

As Bieda [11] asserts "Despite the wealth of existing literature on students' abilities to generate and understand proof, we still know very little about how skills related to justifying and proving are taught in school mathematics particularly in mathematics courses outside of high school geometry". Furthermore, we find very few studies that examine how skills related to mathematical reasoning in general are taught at upper secondary students. Recently, reference [7] reports an effort to endorse improvement of upper secondary students' mathematical reasoning ability by means of conducting lessons based on PBL. In spite of the positive result, it took a few sample. It still need an implementation to a wider subject. To resume, the study aims to develop valid, practice, and effective instruction materials based on PBL to inculcate upper secondary students' mathematical reasoning skills in a wider sample than before. This report constitutes result of the first of the two-yearsplanned research.

\section{METHODS}

The study is a developmental research. It applies the four steps Thiagarajan, Semmel, and Semmel [12] proposed. The researcher divided the four steps into two parts. First part consists of the first three steps and the last step constitutes part two of the research that would take place in the second year. This paper reports some result the researcher got from the first year of the research. The researcher developed all the instruction materials needed. Learning materials taken from trigonometry topic, i.e. trigonometric comparison in four quadrants and related angels, trigonometric identity, and Sine and Cosine rules, which tenth graders should learn. Student's book plays role to help students referring necessary information in the frame of solving problem. Student's work sheet (SWS) contains problems for students to solve which expected inculcating their mathematical reasoning skills. Pre and post-test instrument were developed to measure students' mathematical reasoning skill within four indicators, i.e. (a) Draw logical conclusion; (b) Give explanation on model, fact, properties, relationship, or pattern exists; (c) Make conjecture and proof; and (d) Use of relationship pattern to analyse situation, to make analogy, or to generalize.
The subjects of the research are students from five schools; one class of each consists of 35 students averagely, with Aaccreditation in Deli Serdang District, Binjai, and Medan, North Sumatera Province, Indonesia in Academic Year 2016/2017. Meanwhile, six teachers engaged in the research have varies experiences of teaching. The researcher took role an observer in four classrooms.

Before conducting the lessons, the researcher administered pre-test to get data on previous students' mathematical reasoning skills. Teacher then conducted the lessons, which take four times and ended by administering post-test. Both pre and post-test consist of four problems. During the lessons, an observer observe students' activity while discussing and solving problems either with or without scaffolding from their teacher. The observer recorded some parts of the students' activity. After finishing post-test, students express their perception on and assess the learning materials they have used by responding to a scale of five.

Developing an instruction material, which is intended as an intervention to learning and teaching process, researcher need considering three criteria [13]. That is to say, validity, which refers to relevancy and consistency. Practicality refers to the intervention, that the intervention is usable in the setting for which it has been designed. The research used sheet of 5-scale to obtain data on practicality from the students and sheet of 4scale from the teachers. Sheet of 4-scale was also used for expert validators to judge the validity of the product. Effectiveness refers to the using of product results in desired outcomes. Three experts judge the validity of the materials on content and construct. For this research, it is said valid if its average score equals to or is greater than 3.6. It satisfies practice criteria if the teachers judge that it is eligible for the purpose of the lesson with minimal score 3.6 and the students' respond score on it is minimal 3.5. Last, the intervention is effective if students' MRS improve at least within category low by Hake's criteria [14]. Both pre and post-test of MRS used holistic rubric for scoring 5-scale. It existed four problems, such that ideal score for each test is twenty.

\section{RESULTS AND DISCUSSION}

Although all of the schools involved in the study has Arank, only 15 up to $20 \%$ of them who are ready continuing learning with adequate previous knowledge as well as have intrinsic motivation to learn mathematics. Most of them were not accustomed to learning mathematics in-group, especially in constructivism environment. As this is the case, at the beginning of the lesson, teachers reviewed some important concepts, results, or principle accordingly. Furthermore, teachers also asked them to work on SWS collaboratively and each member of group be responsible of the successful of their group.

Albeit all the teachers perceived the existence of model of teaching based on constructivism, including PBL, they almost never use it to deliver the lesson nor do they ever design lesson to grasp certain high order mathematical thinking. Sometimes, they make students learning mathematics ingroup. Three of them, have engaged in training on teaching 
model based on scientific paradigm. Despite the training, they never design and conduct SWS themselves in pursuing mathematical reasoning skill. On the contrary, all of the teachers regard scientific approach fit for mathematics and should implement it to suitable certain topic.

The three expert validators judged the instruction materials is relevant and consistent to what extent it is designed with average score 3.8. Therefore, the instruction materials fulfill the first criteria. They recommended minor revision on the SWS and students' book. One revision in SWS made based on comment of the validator concerning Fig. 1. One task in the problem concerning to Fig. 1 is to compute the length of segment $D E$, but it does not mention where the location of point $E$. In revision version, it is the name of point of intersection between segment $A C$ and the prolongation of segment $D F$. Another revision is in Students' Book made based on validator's comment concerning Fig. 2. In students' book, which use Fig. 2 as context, it explains the trigonometric comparison only to sine either for angles $\gamma$ or $\alpha$. Though this is intended as a review to remind students on the definition of trigonometric comparison, the validators consider it would be more helpful to students if the researcher present the comparison completely for all.

After revising in accordance to the validators' comment, the researcher then discuss the implementation of the intervention at each school with the teacher. At the first lesson, the teacher oriented each group to work on problems in the SWS 1. This worksheet contains nine problems, which intended to inculcate the ability in drawing logical conclusion and give explanation on model, fact, properties, relationship, or pattern exists, and use of relationship pattern to analyse situation, to make analogy, or to generalize. Tasks in SWS 1 constitute establishing trigonometric comparison in the four quadrants of Cartesian plane and related angles and apply it to solve related problems. All groups in the classrooms were able to complete the tasks but the second part, though time to time the teacher helped by scaffolding. On the second part, some groups were unable to complete the task or did it incorrectly. An example of students' work on problem 9 is shown in Fig. $3 \mathrm{a}$ and Fig. 3b. This problem refers to Fig. 1. Given the length of $B C$ equals 1 , it asks to determine among others the length of $B D, A D, F B, A E$, and $D E$. From Fig. 3a and Fig. 3b which exhibit the students' work, they only calculate the length of $A B$ and $A D$. Then they stop working after calculating the length of $A D$. There did not exist any explanation why they put $\sqrt{ } 2$ on segment $A C$. Moreover, they failed connecting the fact that $\angle \mathrm{BDA}=60^{\circ}$ and conclude from triangle $A E D$ that $\angle \mathrm{EDA}=15^{\circ}$ such that $\angle B D F=45^{\circ}$. This will enable them continue working to compute the length of $F B$, for example.

SWS 2 contained six problems, which is intended to inculcate students' skill in all the four indicators mentioned earlier. All of the groups failed in problem number 6. Besides, no group worked on second part of problem number 5, which demand student's skill in the first and fourth indicator.

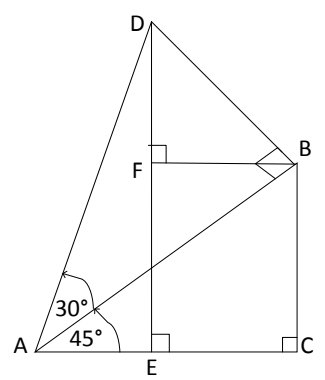

Fig. 1
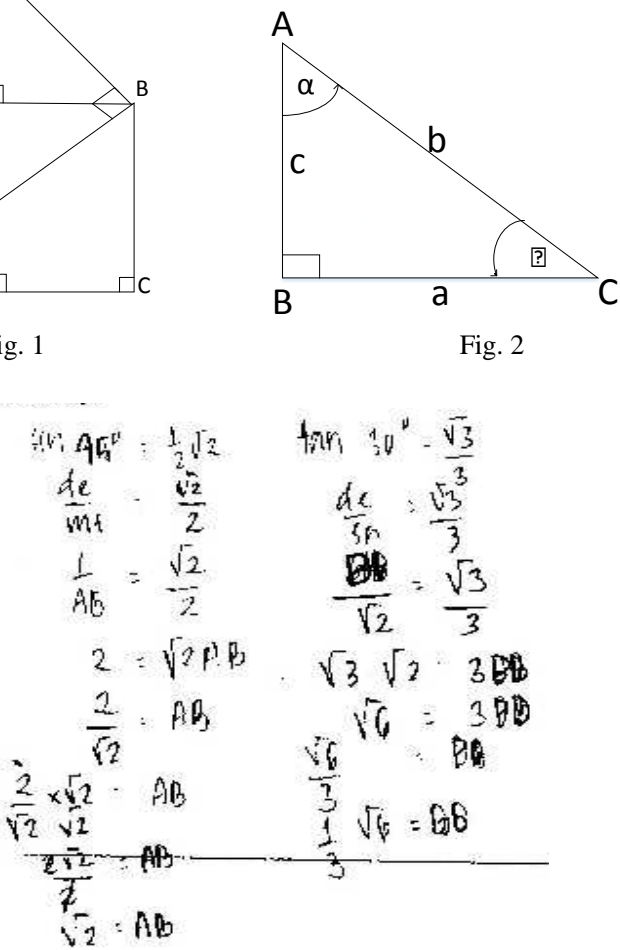

Fig. 3a

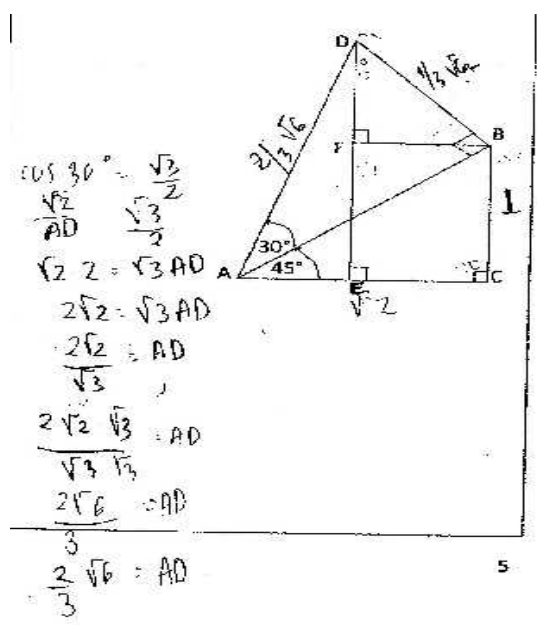

Fig. 3b
Though the facts $\operatorname{cosec} x+\cot x=3$ and $\operatorname{cosec} x-\cot x=$ $1 / 3$ were in hand, they did not perceive it only need to sum up both equations and the relation of cosec to sine then Pythagoras to get the value of $\cos x$. For problem number 6 part (a), it was given $x=2 \cos \theta$ and $y=4 \sin ^{2} \theta-1$. The task is to establish a relationship between $x$ and $y$. Some groups were not able to see that they only needed, for example, squaring $x$ to get a tight relationship with $y$. For this problem they only wrote something nonsense (see Fig. 4). 


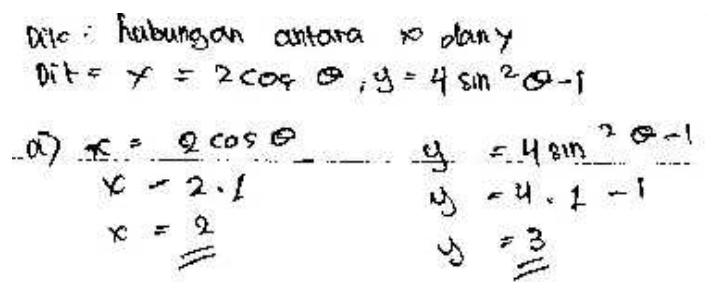

Fig. 4

On the contrary, other groups did meaningful effort. They perceive the relationship between $\sin ^{2} \theta$ and $\cos ^{2} \theta$ and take advantage of it to relate $x$ and $y$ (see Fig. 5).

The last SWS contained five problems. Similar to SWS 2, all of the problems in SWS 3 pursuit the four indicators mentioned above. All tasks are based on sine rule. Most groups were able to complete the tasks but problem 4 . In this task, given $\sin x+\sin y=a$ and $\cos x+\cos y=a$. It demands to determine $\sin x+\cos x$ in $a$. This task inculcate students' skills in the first and fourth indicators It needs multiple steps to complete the task, the ability to create new equation from old ones, operate equation in hand to lead to tentative result, and draw conclusion by connecting the result to previous ones. Instead of doing this, the students only wrote something nonsense (see Fig. 6). Overall, considering their work on the three SWS, the researcher conclude there exists progress in students' mathematical reasoning skills.

Concerning to the instructional materials the researcher developed, average score the teachers gave is 4.6, which means that it is eligible for the purpose of the lesson or usable in the setting for which it had been designed. Meanwhile, students' average score towards the instruction materials is 3.6. The researcher therefore concluded that the instruction materials developed satisfies practicality criteria. Table 1 shows the statements posed to reveal students' perception and assessment on the learning material. They agreed the students' book help them understanding topic being learned, though they expected it should contain more explanation. They also admitted it endorsed to relate between knowledge though they were not sure whether it attracted their interest to learning.

Concerning to the SWS, on general, they perceived the problems in it were difficult, though making sense and

$$
\begin{aligned}
& \text { (a) } x=2 \cos \theta, y=4 \sin ^{2} \theta-1 \\
& \text { Dusawat: } \\
& \text { 1) } x=2 \cos \theta \\
& y=4 \sin ^{2} \theta-1 \\
& y=4-4 \cos ^{2} \theta-1 \\
& y=3-4 \cos ^{2} \theta \\
& y=3-(\cos \theta)^{2} \\
& y=3-x^{2} \text {. }
\end{aligned}
$$

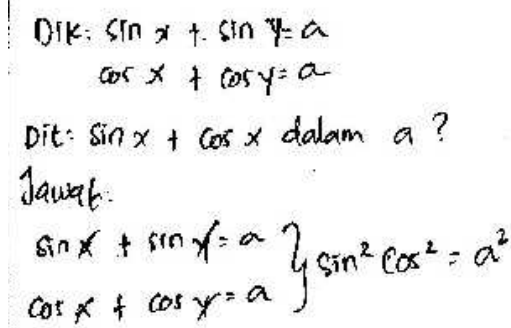

Fig. 6

believed that they would be able to solve them if given some help. Moreover, they admitted the SWS endorsed them to work more actively than ever and enhanced their skills by solving them.

The last component to see is the effectiveness of the instructional materials. To this end, the researcher had administered pre and post-test on students' mathematical reasoning skills. On the pre-test, average score was 27.88 and on the post-test, it was 37.96. Those scores had been converted to 100-scale from 20-scale. Numerically, there existed an improvement. To know qualitatively the category of this improvement, the researcher used Hake's average normalized gain $(\mathrm{g})$, i.e.

$$
g \equiv \frac{G}{G_{\max }}=\frac{s_{f}-s_{i}}{100-s_{i}} .
$$

$\mathrm{S}_{\mathrm{f}}$ stands for final score and $\mathrm{S}_{\mathrm{i}}$ stands for initial score. By substituting the scores, one get the value of $g=0.14$, which is less than 0.3. Hake categorized this improvement low.

The low improvement occurred in the research, surely due to many causes. Initial data had revealed that the students were not accustomed to learning in scientific approach environment. Even though, they ever learned in-group, but it was not in the frame of solving problems. Moreover, it is a certainly challenge conducting a PBL lesson in a mathematical classroom with only 15 up to $20 \%$ of students ready continue learning by means of having adequate previous knowledge [15 and 16]. They even resist on the approach such as PBL. Most of them demanded teacher to teach as usual, that is explain the theory then give examples and continue working on problems similar to examples. That is why they wished the students' book (SB) contained more explanation and more workedproblems. Actually, the SB was designed as supplement to textbook they used.

Theoretically, PBL demands teachers keeping the learning environment in which students engage in high-level thinking and reasoning. For lack of experience in conducting lesson using teaching model such as PBL, the teachers were not able scaffolding fluently. Consequently, it occurred time passed by inefficiently, which also stressed in [11].

Fig. 5 
TABLE 1 Students perception and assessment toward the learning materials (in percentage)

\begin{tabular}{|l|l|l|l|}
\hline No & Statement & Agree & $\begin{array}{l}\text { Not } \\
\text { agree }\end{array}$ \\
\hline 1 & SB help me comprehend the materials more & 94 & 4 \\
\hline 2 & SB lack of explanation & 48 & 44 \\
\hline 3 & SB endorse me relating knowledge & 88 & 4 \\
\hline 4 & Difficult to pursuit SB caused of discontinuities & 24 & 64 \\
\hline 5 & SB is attracting and interesting & 68 & 20 \\
\hline 6 & SB could not be used learning resource & 0 & 72 \\
\hline 7 & Problems in SWS are difficult & 64 & 24 \\
\hline 8 & We could solve problems in SWS with help & 92 & 8 \\
\hline 9 & Problems in SWS endorse learning more actively & 92 & 4 \\
\hline 10 & Problems in SWS are nonsense & 8 & 72 \\
\hline 11 & $\begin{array}{l}\text { Solving problems in SWS enhance mathematical } \\
\text { skills }\end{array}$ & 94 & 0 \\
\hline 12 & I am able solving problems in SWS alone & 14 & 46 \\
\hline 13 & Tasks in SWS are not interesting to discuss & 0 & 84 \\
\hline 14 & SWS's language is difficult to understand & 16 & 68 \\
\hline
\end{tabular}

The lack of scaffolding was also noted in the observation sheet on students' activity. Emerged neither different idea or any suggestion, nor any effort to work in different way or pose question that need deep explanation in part of the students. All of those high-level thinking or reasoning will emerge in case teacher pose varies, connecting and challenging questions.

Based on experiences, the teachers said trigonometry is one of the most difficult topic for students to handle. It contains too many identities, possibly relationships among others, possibilities to develop new relation, and connections to geometry which also difficult for them. It is therefore, more of the students have less intention, perseverance, and passion to work on it. It certainly contribute to the weakness of students' mathematical reasoning skills.

\section{CONCLUSION}

The research produced an instructional device satisfies three criteria, i.e. validity, practicality, and effectiveness. As a model of teaching, PBL is reliable to inculcating students' mathematical reasoning skills. It is therefore suggested the teacher to applying the device in their classroom especially while pursuing the goals aforementioned. To grasp more successfulness, it is preferable the teacher who conduct the lesson master the teaching model used and be able to apply it fluently.

\section{Acknowledgment}

This research was supported by the Ministry of Research, Technology and Higher Education of the Republic of Indonesia. The authors are thankful to Rector of State
University of Medan, Research Director, and Dean of Faculty of Mathematics and Natural Sciences for providing necessary facilities to conduct the research.

\section{REFERENCES}

[1] National Council of Teachers of Mathematics, "Principles and Standards of School Mathematics". Reston, VA: NCTM, 2000.

[2] Indonesian Ministry of Education and Culture, "Kurikulum 2013". Jakarta: Kemendikbud, 2013.

[3] Indonesian Ministry of National Education, "Permendiknas, No. 23". Jakarta: Kemendiknas, 2006.

[4] I. V. S. Mullis, M. O. Martin, P. Foy, A. Arora, "TIMSS 2011 International Result in Mathematics". Boston, MA: TIMSS and PIRLS International Study Center, 2012.

[5] I. V. S. Mullis, M. O. Martin, P. Foy, M. Hooper, "TIMSS 2015 International Result in Mathematics". Chestnut Hill, MA: TIMSS and PIRLS International Study Center, 2016.

[6] J. A. Dahlan, "Meningkatkan Kemampuan Penalaran dan Pemahaman Matematik Siswa Sekolah Lanjutan Tingkat Pertama Melalui Pendekatan Pembelajaran Open-Ended". (Doctoral dissertation, UPI, Bandung), 2004.

[7] E. E. Napitupulu, D. Suryadi, Y. S. Kusumah, "Cultivating Upper Secondary Students' Mathematical Reasoning Ability And Attitude Towards Mathematics Through Problem-Based Learning". Journal on Mathematics Education, Vol. 7, No. 2, pp. 61-71, 2016.

[8] F. Shadiq, "Laporan Hasil Seminar dan Lokakarya Pembelajaran Matematika" Yogyakarta: P4TK (PPPG) Matematika, 2007.

[9] F. Jalal, M. Samani, M. C. Chang, R. Stevenson, A. B. Bagatz, S. D. Negara, "Teacher Certification in Indonesia: A Strategy for Teacher Quality Improvement". Indonesia: Department Pendidikan Nasional Indonesia, 2009.

[10] I. V. S. Mullis, M. O. Martin, E. J. Gonzales, S. J. Chrowstowski, "TIMSS 2003 International Mathematics Report". Chestnut Hill, MA: TIMSS and PIRLS International Study Center, 2004.

[11] K. N. Bieda, "Enacting Proof-Related Tasks in Middle School Mathematics: Challenges and Opportunities". Journal for Research in Mathematics Education, Vol. 41, No. 4, 351-382, 2010.

[12] S. Thiagarajan, D. S . Semmel, \& M . Semmel, "Instructional Development for Training Teachers of Exceptional Children. A Sourse Book". Blomington: Central for Innovation on Teaching the Handicapped, 1974.

[13] N. Nieveen, \& E. Folmer, "Formative Evaluation in Educational Design Research". In Plomp, \& Nieveen (Eds.), Educational Design Research. Enschede: SLO, 2013.

[14] R. R. Hake, "Interactive-Engagement versus Traditional Methods: A Six-Thousand-Student Survey of Mechanics Test Data for Introductory Physics Courses". Am. J. Phys., 66 (1), P. 65, 1998.

[15] M. Henningsen, \& M. K. Stein, "Mathematical Tasks and Student Cognition: Classroom-Based Factors That Support and Inhibit HighLevel Mathematical Thinking and Reasoning". Journal for Research in Mathematics Education, Vol. 28, No. 5, 524-549, 1997.

[16] E. E. Napitupulu, "Pengaruh Pembelajaran Berbasis Masalah atas Kemampuan Penalaran dan Pemecahan Masalah Matematis serta Sikap terhadap Matematika Siswa Sekolah Menengah Atas". (Doctoral dissertation, UPI, Bandung), 2011. 